\title{
Woolly oak aphids Stegophylla brevirostris Quednau and Diphyllaphis microtrema Quednau (Insecta: Hemiptera: Aphididae) ${ }^{1}$
}

\author{
Susan E. Halbert ${ }^{2}$
}

\section{Introduction}

Woolly oak aphids are conspicuous pests on oak (Quercus spp.), because they are covered with large amounts of flocculent wax. Two genera of woolly oak aphids occur in Florida, each including one known native Florida species. One species, Stegophylla brevirostris Quednau, is common, and the other, Diphyllaphis microtrema Quednau, is rare.

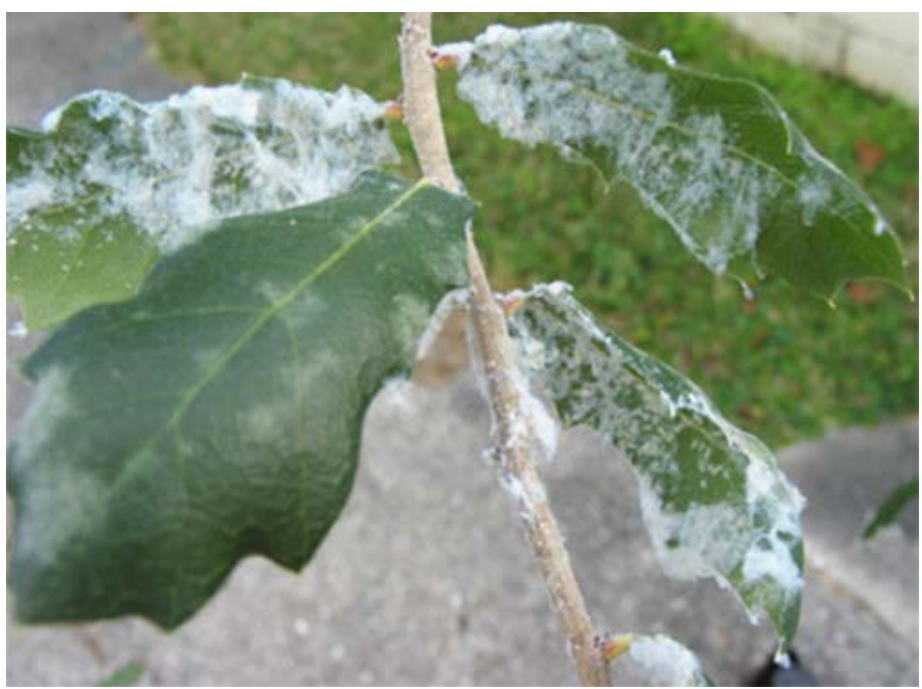

Figure 1. Stegophylla brevirostris Quednau colony on oak. Credits: Susan E. Halbert

\section{Distribution}

Both species occur in eastern North America. Stegophylla brevirostris is a pest only in Florida.

\section{Description}

Florida woolly oak aphids can be recognized easily by the large quantities of woolly wax that they secrete (Figs. 1,2). Beneath the wax, the aphid bodies are pale. Young nymphs can be pale green, and they tend to be more mobile than adults. Excreted honeydew forms brown droplets in the wax. Separation of the two species is based on microscopic characters. Both species have short appendages and porelike siphunculi. They lack the tubular siphunculi present in many species of aphids. Species of Stegophylla have larger siphuncular pores, with a ring of setae surrounding them (Figs. 3, 4). Species of Diphyllaphis have minute siphuncular pores that lack setae (Figs. 5, 6). The majority (59\%) of DPI records for Stegophylla brevirostris indicate that live oak (Quercus virginiana Mill.) was the host. A few records came from other species of oaks. Diphyllaphis microtrema has been found on an assortment of oaks, including live oak, seemingly without a preference for species.

1. This document is EENY574, one of a series of the Entomology and Nematology Department, UF/IFAS Extension. Original publication date October 2013. Visit the EDIS website at http://edis.ifas.ufl.edu.

2. Susan E. Halbert, Florida Department of Agriculture and Consumer Services, Division of Plant Industry, Gainesville, FL 32611.

The Institute of Food and Agricultural Sciences (IFAS) is an Equal Opportunity Institution authorized to provide research, educational information and other services only to individuals and institutions that function with non-discrimination with respect to race, creed, color, religion, age, disability, sex, sexual orientation, marital status, national origin, political opinions or affiliations. U.S. Department of Agriculture, Cooperative Extension Service, University of Florida, IFAS, Florida A\&M University Cooperative Extension Program, and Boards of County Commissioners Cooperating. Nick T. Place , Dean. 


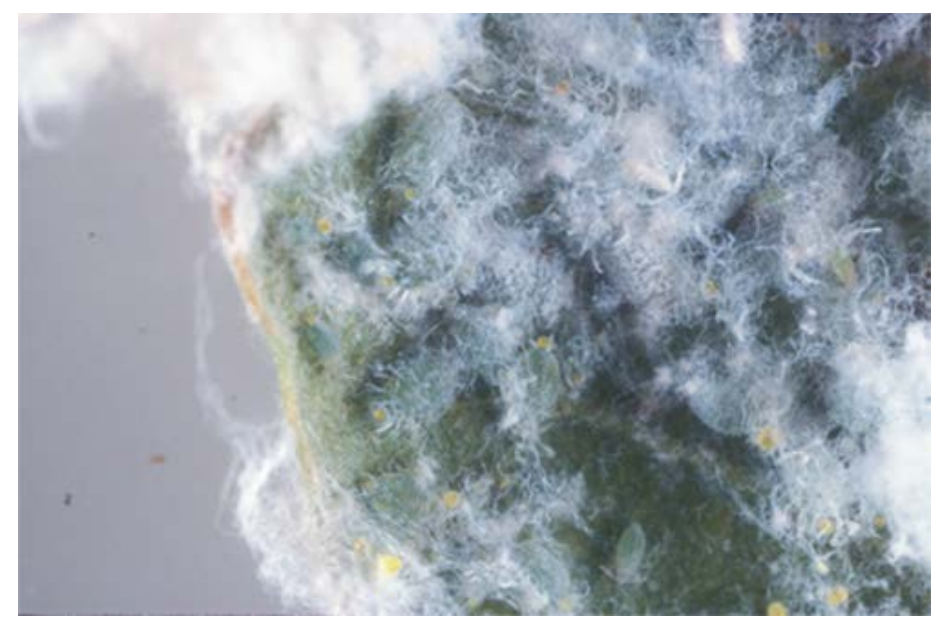

Figure 2. Stegophylla brevirostris Quednau on live oak. Credits: Lyle Buss, University of Florida

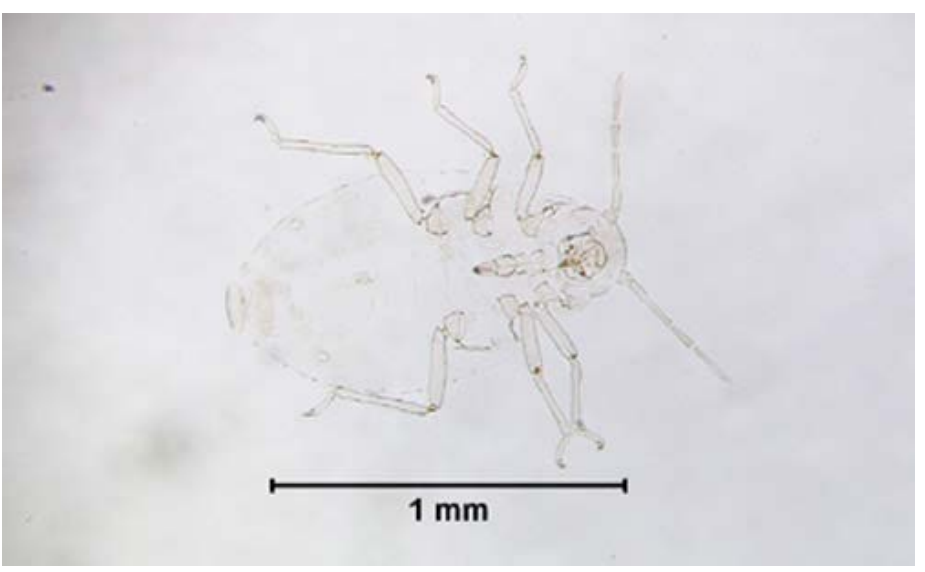

Figure 3. Stegophylla brevirostris Quednau.

Credits: Susan E. Halbert

Stegophylla brevirostris only recently acquired a valid name. In the past, it was known as Stegophylla querci (Fitch) or Stegophylla quercicola (Monell). Stegophylla querci is not a valid name, because the species was synonymized in another genus (Anoecia) (Remaudière and Remaudière 1997). Quednau (2010) provided the new name, Stegophylla davisi Quednau, for Stegophylla querci; however, Stegophylla davisi also does not match Florida specimens. Stegophylla quercicola is a valid species, but similarly, it does not match the Florida specimens. Thus, a new name was needed for the Florida aphids. Stegophylla brevirostris was described in Quednau (2010). The species is distinguished from others in the genus by its short ultimate rostral segment and lack of empodial setae in viviparous forms.

\section{Life History}

Stegophylla brevirostris is permanently anholocyclic (no sexual or egg-laying forms) in Florida. We have raised Stegophylla brevirostris for years at DPI, Gainesville and

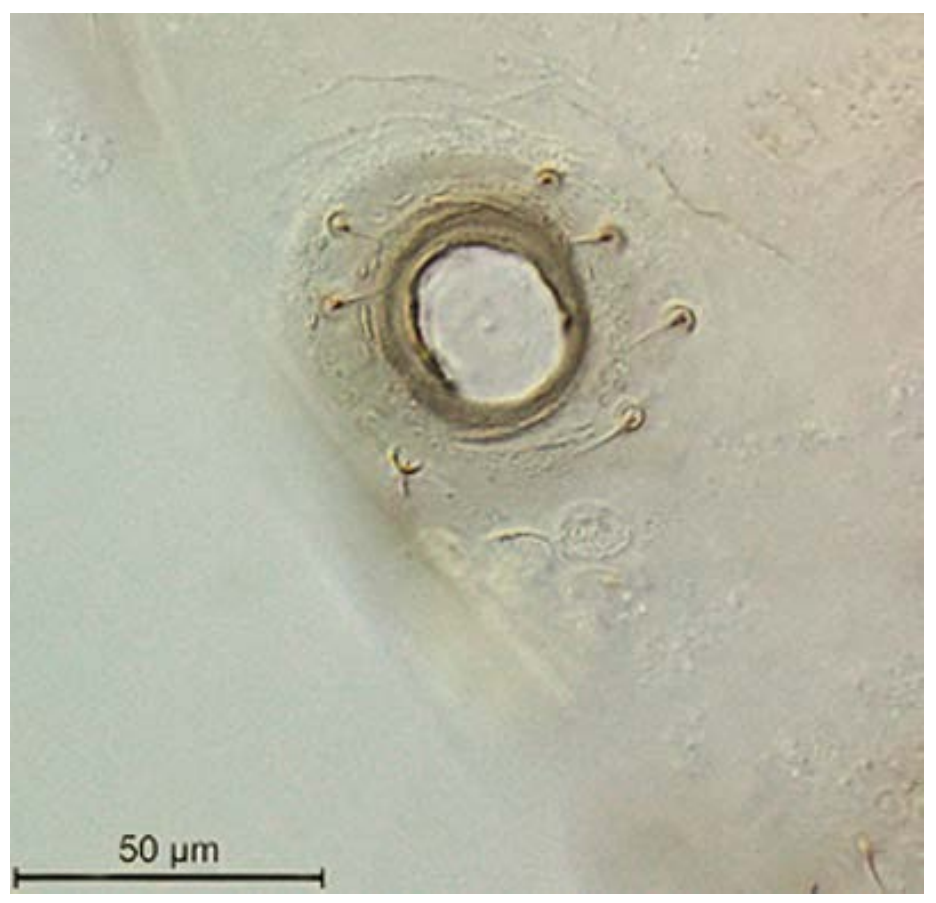

Figure 4. Stegophylla brevirostris siphunculus. Credits: Ian C. Stocks

have never seen any oviparae (egg-laying females) or males in the colony. All forms throughout the year are livebearing females. Moreover, no winged forms are known in Florida. One ovipara and one winged male are known from Maryland (Quednau 2010). Thus, in northern climates, Stegophylla brevirostris seemingly has a holocycle, with overwintering eggs. Among Stegophylla species, the only known winged forms are the males that occur in the fall and mate with the oviparae to produce overwintering eggs. It is not known how these aphids disperse, but possibly they are picked up and carried by birds and larger flying insects because of the sticky wax that surrounds the bodies of the aphids

\section{Hosts}

Both species feed on various species of oaks. Stegophylla brevirostris has a preference for live oak, whereas Diphyllaphis microtrema uses a mix of species.

\section{Survey and Detection}

Woolly oak aphids are conspicuous because of the white woolly wax produced on the undersides of the leaves. Sometimes these aphids are mistaken for mealybugs or whiteflies. 


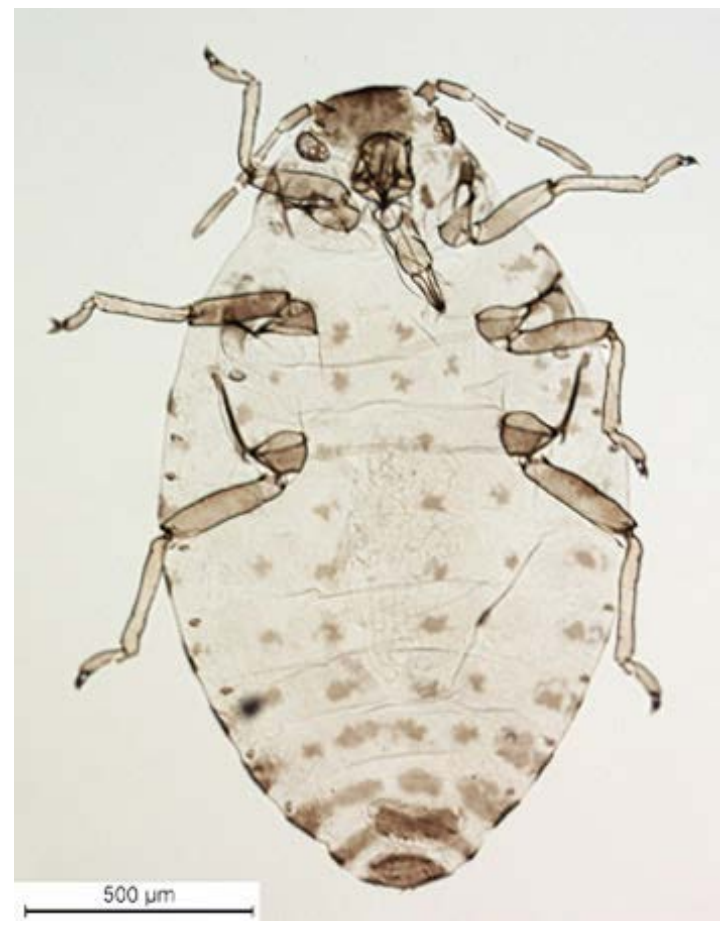

Figure 5. Diphyllaphis microtrema Quednau.

Credits: Ian C. Stocks

\section{Control}

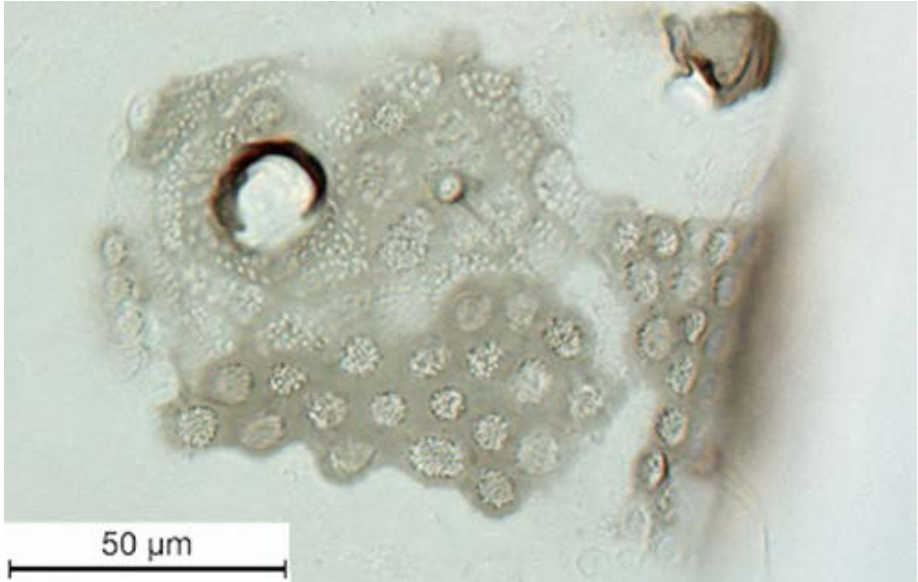

Figure 6. Diphyllaphis microtrema Quednau siphunculus.

Credits: Ian C. Stocks

Consult the local University of Florida Extension personnel for control of woolly oak aphids. These are native species with native natural enemies. In most cases, control will not be needed. However, these species can make a significant mess, so control might be warranted in situations where populations are high, and plant appearance is important.

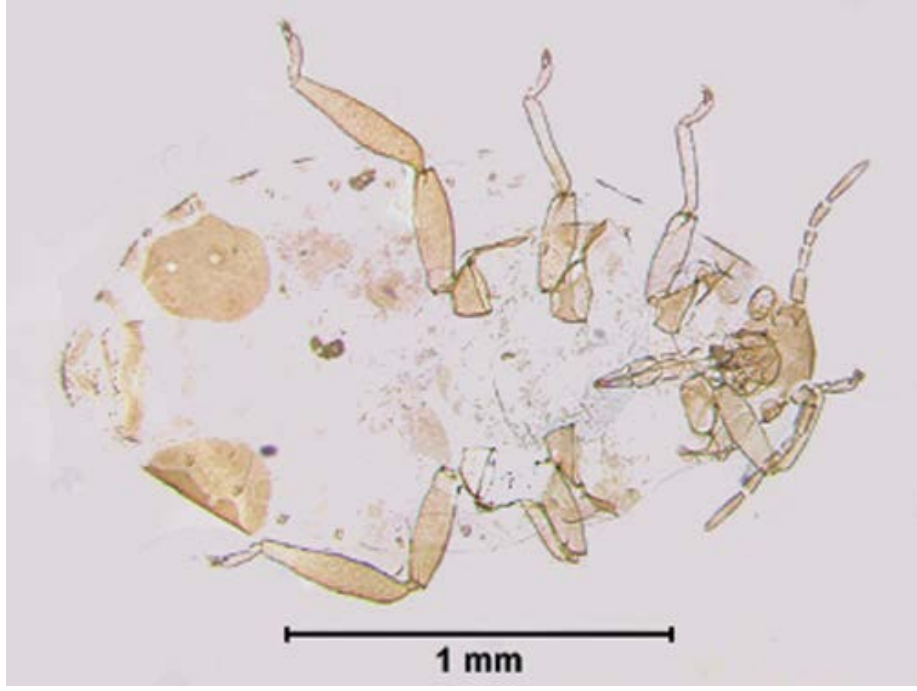

Figure 7. Diphyllaphis microtrema Quednau ovipara. Credits: Susan E. Halbert and Lyle Buss, University of Florida

\section{Selected References}

Quednau, F.W. 2010. Memoirs of the American Entomological Institute Volume 83. Atlas of the Drepanosiphine aphids of the world part III: Mindarinae Tullgren 1909; Neophyllaphidinae Takahashi, 1921; Lizeriinae E.E. Blanchard, 1923; Pterastheniinae Remaudière \& Quednau, 1988; Macropodaphidinae Zachvatkin \& Aizenberg, 1960; Taiwanaphidinae Quednau \& Remaudière, 1994; Spicaphidinae Essig, 1953; Phyllaphidinae Herrich-Schaeffer in Koch 1857; Israelaphidinae Ilharco, 1961; Saltusaphidinae Baker, 1920 (Hemiptera: Sternorrhyncha, Aphididae). The American Entomological Institute, Gainesville, FL. 361 pp. (See pages 111 and 265 for description and figures, respectively, of Stegophylla brevirostris).

Remaudière, G. \& M. Remaudière. 1997. Catalogue des Aphididae du Monde. INRA. Versailles. 478p 